\title{
G

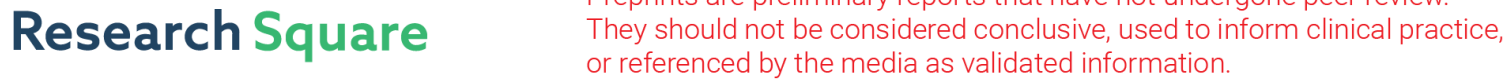 \\ Exotic Brittle Star Interactions With Native Octocoral Epizoites: An Endemic Benthic Ctenophore in Peril?
}

\section{Peter Glynn}

University of Miami Rosenstiel School of Marine and Atmospheric Science

\section{Brian Coffman}

University of Miami - Coral Gables Campus: University of Miami

Kyle Detloff

NOAA-SE Fisheries Science Center: Southeast Fisheries Science Center

Joshua Dominguez

University of Miami Rosenstiel School of Marine and Atmospheric Science

\section{Philip Gilette}

University of Miami Rosenstiel School of Marine and Atmospheric Science

\section{Nicholas Martinez}

University of Miami Rosenstiel School of Marine and Atmospheric Science

Nicolas Jones

Nova Southeastern University Oceanographic Center: Halmos College of Natural Sciences and Oceanography

\section{B. Riegl ( $\square$ rieglb@nova.edu )}

Nova Southeastern University https://orcid.org/0000-0002-6003-9324

\section{Research Article}

Keywords: marine biological invasion, alien Ophiothela, octocoral hosts, Coeloplana, Caprella predation, subtropical Florida, behavioral effects

Posted Date: April 5th, 2021

DOI: https://doi.org/10.21203/rs.3.rs-370115/v1

License: (c) (i) This work is licensed under a Creative Commons Attribution 4.0 International License. Read Full License

Version of Record: A version of this preprint was published at Marine Biology on August 18th, 2021. See the published version at https://doi.org/10.1007/s00227-021-03927-7. 


\section{Abstract}

Widespread and large populations of the exotic eastern Pacific ophiuroid brittle star Opthiothela mirabilis now occur in southeastern Florida, extending the range of this recently introduced species from southern Brazil northward to the eastern Caribbean Sea and Florida. The Florida brittle stars, representing two lineages, are epibionts on shallow (3-18 m depth), tropical/subtropical plexaurid (e.g., Eunicea spp., Muricea elongata) and gorgoniid (Antillogorgia spp.) octocorals. The scope of this study includes recent distributional records of $O$. mirabilis in south Florida, field abundances in relation to the cohabiting endemic ctenophore Coeloplana waltoni, behavioral observations of the ophiuroid, ctenophore and the predatory amphipod Caprella penantis, as well as a laboratory experiment testing the effects of the alien ophiuroid on the native ctenophore. Individuals of 0 . mirabilis have been collected near St. Lucie Inlet, extending its northern-most range by about $110 \mathrm{~km}$ since 2019. Two years of field sampling have demonstrated significant declines of the native, benthic ctenophore with increasing abundances of the exotic ophiuroid. Evidence suggests that the ophiuroid is negatively affecting the abundances of the ctenophore through interference competition, greatly aided by its abrasive armature of calcareous spines, plates and hooks. Sporadic and intense predation by a caprellid amphipod (Caprella penantis) also probably contributes to the ctenophore's decline, but to a lesser extent than that caused by the ophiuroid. Adding to the risk of extinction of $C$. waltoni is its narrow requirement of living octocorals as hosts and restricted distribution in southeast Florida and the Bahamas.

\section{Introduction}

Some demonstrated serious effects resulting from the introduction of non-native or exotic marine species on native biota are a decrease in biodiversity, local species extirpations, extinctions, and at the ecosystem level changes in community structure and function (Katsanevais et al., 2014; Anton et al., 2019). Such impacts are concerning regarding the recent acceleration in marine bioinvasions (Seebens et al., 2017; Pyšek et al., 2020). Relatively recent introductions of three species of sun corals (Tubastraea spp.) in Brazil (de Paula and Creed, 2004), the Caribbean Sea, Florida and the Gulf of Mexico (Fenner, 2001; Fenner and Banks, 2004; Sammarco et al. 2015) have resulted in the competitive exclusion of numerous native species. The present study focuses on the exotic brittle star, Ophiothela mirabilis, which was first reported in the western Atlantic from the south coast of Brazil in 2000 (Hendler et al. 2012). Although the corals and brittle star have evolved very different life histories, like Tubastraea spp., 0 . mirabilis possesses several traits that allow for rapid colonization of new habitats in western Atlantic warm waters. Sun corals are sessile, epibenthic species with major impacts on benthic communities (Lages et al. 2011; Sammarco et al., 2015; Luz et al., 2017; Guilham et al., 2020) whereas individuals of O. mirabilis are vagile, highly active epizoites usually associated with diverse benthic taxa, especially cnidarians and sponges (Mantelatto et al. 2016; Fortunato and Lôbo-Hajdu 2021; Tavares et al. 2021). While both Tubastraea spp. and $O$. mirabilis can potentially have major effects on sessile benthic species, ophiuroids can also impact cohabiting epibionts. 
Marine organisms exhibiting complex body structures often host numerous symbiotic metazoan associates, thus promoting local and regional biodiversity. These associations are realized across a broad range of seascape depths, from the shallow littoral zone (Bayer, 1961; Goh et al., 1999; Sánchez, 2016) to mesophotic (Maggione et al., 2020) and deep continental margin environments (Buhl-Mortensen et al. 2010). Early on, Bayer (1961) recognized the great variety of organisms associated with tropical western Atlantic octocorals - zooxanthellae (dinoflagellates); parasitic copepods, cirripeds, pycnogonids, and gastropods; epizootic cnidarians, ctenophores, polychaete worms, porcellanid and spider crabs, hippolytid shrimp, gastropod molluscs, and ophiuroid echinoderms. Our knowledge of the diversity of octocoral communities, including octocoral microbes (viruses, bacteria), fungi, protozoans, invertebrates and fishes has been greatly augmented recently (e.g., Van Oppen et al. 2005; Sánchez 2016; McCauley et al. 2020) in shallow western Atlantic, Indo-Pacific, and eastern Pacific regions, but is still greatly understudied.

The focus of this study is on the alien ophiuroid Ophiothela mirabilis and its interactions with the native benthic ctenophore Coeloplana waltoni, both epizoites on species of octocorals. We provide recent data on the occurrence and abundance of the non-native ophiuroid on octocorals across approximately $78 \mathrm{~km}$ of coastline, from Hollywood Beach to West Palm Beach, Florida. A seven-day laboratory experiment simulating ophiuroid-ctenophore interactions was performed to further investigate this competitive association and the cause of natural variations in the epizoite relative abundances. Attention is also directed to the recent occurrence of the amphipod, Caprella penantis, a sporadic co-inhabitant of octocorals. The abundances and behaviors of the ophiuroid and caprellid suggest competitive and predatory interactions, respectively, leading to negative impacts affecting the abundance of the benthic ctenophore. This study offers an opportunity to address questions relating to extinction research in the earliest stages of invasion (Sax and Gaines, 2008). A time-lag to extinction may exist for the benthic ctenophore under competition by the introduced ophiuroid and intense predation by the caprellid. To understand this, the ophiuroid invasion needs to be tracked to follow how the ophiuroid changes the abundance of the ctenophore. Interference competition by the ophiuroid may transform the ctenophore's microhabitat sufficiently to endanger their presence. Finally, we propose a mechanism of ctenophore exclusion by the incidental and frequent abrasive activities of the heavily armored 0 . mirabilis.

\section{Materials And Methods}

Species

Six plexaurid and three gorgoniid octocoral host species were sampled in this study with an emphasis on Eunicea asperula Milne Edwards \& Haime, 1857; Eunicea clavigera Bayer, 1961; Eunicea flexuosa (Lamouroux, 1821); Eunicea tourneforti Milne Edwards \& Haime, 1857; and Muricea elongata Lamouroux, 1821. Table 2 in Glynn et al. (2020) lists all octocoral species examined in this and previous studies with corresponding museum catalog numbers. Sánchez and Wirshing (2005) provide species specific characteristics. The non-native ophiuroid Ophiothela mirabilis Verrill, 1867 consists of beige and orange color morphs in Florida, in two closely related lineages (Alitto et al., 2020; Glynn et al., 2020). 
Coeloplana waltoni Glynn, Bayer, Renegar, 2014 is a native south Florida benthic ctenophore (Glynn et al. 2014). Caprella cf. penantis Leach, 1814, an octocoral epizoite, belongs to a complex of cryptic, amphipod species and is probably not cosmopolitan in distribution (Cabezas et al., 2013; Paz-Rios et al., 2014).

Field sampling

Octocoral collections were made at the Dania Beach study site $\left(80^{\circ} 06.344^{\prime} ; 26^{\circ} 03.506^{\prime}\right)$ over a 19 -month period, July 2018-February 2020 .Octocoral side branches approximately $15-20 \mathrm{~cm}$ in length, from colonies with 0 . mirabilis present, chiefly species of Eunicea and Muriceaelongata, were cut free, bagged separately and then transported to the laboratory in an insulated cooler with aerated sea water. The number of colonies sampled in each collection ranged from 16 to 30 , and the ophiuroids collected were predominantly the beige color morphs. See Glynn et al. (2020) for additional details of routine field sampling. All specimens at the Blue Heron Bridge site were collected under a Special Activity License (SAL-20-2267-SR) issued to Phillip R. Gillette by the Florida Fish and Wildlife Conservation Commission, Division of Marine Fisheries Management, Tallahassee, Florida.

Sampling to determine the spatial pattern of occurrence of $O$. mirabilis involved observations at several sites off coastal Ft. Lauderdale, at locations north and south of Port Everglades. Ten to 40 plexaurid and ten to 40 gorgoniid colonies were examined at 22 sites from April to December 2020. Occurrence and abundances at survey sites were estimated according to the following qualitative scale: rare, 0 to 1-2 ind. on $<5 \%$ of colonies; moderately common, $5-10$ ind. on $5-20 \%$ of colonies; abundant, $20+$ ind. on several branches of over $20 \%$ of colonies. At 16 of the sites located around Port Everglades, prevalence was calculated quantitatively (percent of colonies with 0 . mirabilis present) and prevalence interpolated using an inverse distance weighted method (IDW) in QGIS (Bartier \& Keller 1996). Geographic positions were obtained by means of GPS.

Behavioral observations

The feeding behavior of individuals of $O$. mirabilis were viewed in the field during the day and night. Competitive and predatory observations were made within 2 to 3 hours after collection, microscopically (8-35X) under subdued lighting in the laboratory on octocoral branches with their normal complement of epizoites. Interactions between individuals of $O$. mirabilis and their octocoral hosts also were observed in the laboratory during feeding and non-feeding periods.

\section{Experimental procedure}

The plexaurid octocoral host species employed in the laboratory experiment were Euniceasuccinea (Pallas, 1766) and Eunicea tourneforti Milne Edwards \& Haime, 1857. These octocoral species were the only two found consistently hosting both the non-native ophiuroid Ophiothela mirabilis Verrill, 1867 and the endemic benthic ctenophore Coeloplana waltoni Glynn, Bayer \& Renegar, 2014. The common beige color morph of 0 ,mirabilis was employed in this experiment (Glynn et al. 2020). The experimental animals 
were collected off Lauderdale by the Sea, Florida $\left(26.1920^{\circ} \mathrm{N} ; 80.0964^{\circ} \mathrm{W}\right)$ on 27 October 2020 at 4-5 meters depth. The basal end of each lateral branch was trimmed until the branch measured $10 \mathrm{~cm}$ in length. A total of 10 separate 4 litercontainers, each with a vertically oriented octocoral branch with (experimental) or without (control) individuals of the non-native brittle star were randomly placed in a linear array with respect to the light source. All octocoral branches contained ctenophore epizoites with initial densities: experimental (with brittle stars), mean C. waltoni density (no. ind. $10 \mathrm{~cm}^{-1}$ branch) $=7.2$, range $=6-9$; controls (without brittle stars), mean $C$. waltoni density $=7.6$, range $=6-10$. Initial experimentalO . mirabilis density, mean $=5.0$, range $=3-6$; control $=0$. The water was gently aerated and stirred continuously with magnetic stirring bars, creating a flow rate of approximately $8 \mathrm{~cm} \mathrm{~s}^{-1}$. One liter of water with naturally present plankton was changed out daily in each container. Both brittle stars and ctenophores were observed feeding on plankton during daylight hours. Ctenophores were occasionally observed feeding at night. The experiment was conducted for 7 days; data on epizoite densities and location on octocoral hosts were collected daily. Caprellids were absent from the experiment.

Statistical analyses

Two statistical models were fit to densities of the three species (O. mirabilis, $C$. waltoni, C. penantis) inhabiting the $10 \mathrm{~cm}$ octocoral branches (406 total branches collected over 16 surveys) using the $\mathrm{R}$ package $g / m m T M B$ (Brooks et al., 2017). The first model, to analyze trends in species counts over the survey period, employed a zero-inflated first order negative binomial (NB1) response structure $(\phi=6.79)$ with survey as a random effect (a branch random effect was dropped due to zero estimated variance). The second model, to examine the relationship between the abundance of $C$. waltoni and co-occurring species on octocorals, was fit using a standard NB1 response structure $(\phi=9.53)$ and survey random effect. Fixed effects were selected by AIC from models fit by maximum likelihood, with the final models fit by restricted maximum likelihood. Visual examination of simulated scaled residuals indicated assumptions were met sufficiently for both models. Inference on parameters was performed by employing tests with denominator degrees of freedom estimated using the inner-outer method (Pinheiro and Bates, 2000).

Laboratory experimental results of the effects of the ophiuroid $O$. mirabilis on the benthic ctenophore $C$. waltoni were tested according to the following procedure. A generalized linear mixed model with Poisson response was fit by maximum likelihood to $C$. waltoni counts across seven days of observation under experimental ( $O$. mirabilis present; $\mathrm{n}=5)$ and control $(O$. mirabilis absent; $\mathrm{n}=5)$ conditions. Correlation between repeated measurements was modeled with a heterogeneous AR(1) structure. Type III Wald tests with Kenward-Roger degrees of freedom indicated that reductions in counts over time by treatment were best modeled as second-degree polynomials; there was no evidence that time or treatment effects differed between octocoral host species. Studentized residual plots indicated model assumptions were met sufficiently. To test the overall effect of $O$. mirabilis on $C$. waltoni abundance over time, a nested reduced model without treatment effects was fit as above and compared to the full model using a drop in deviance Chi-square test. Models were fit using SAS/STAT software, version 9.4, PROC GLIMMIX. 


\section{Results}

Field observations

In the 9-month sampling surveys, 0 . mirabilis was present on plexaurid and/or gorgoniid colonies at 18 of 22 sites, including the northernmost site surveyed near West Palm Beach (Fig. 1). Abundance varied spatially, with two hotspot locations identified, on the inner reef (10 m depth) offshore of Port Everglades and on the nearshore ridge complex (5 $\mathrm{m}$ depth) at Hollywood/Hallandale Beach. Individuals of $O$. mirabilis were found on $100 \%$ of colonies at three sites, were abundant at a further three, moderately common on plexaurid colonies at seven sites, moderately common on gorgoniid colonies at four sites and rare at four sites. Quantitative assessment around Port Everglades revealed that $24.37 \%( \pm 34.32 \%$ SD) of octocoral colonies hosted O.mirabilis, $29.6 \%( \pm 42.38 \%$ SD) of gorgoniids and $19.16 \%( \pm 19.16 \%$ $\mathrm{SD})$ of plexaurids.

A single survey was performed in a brackish water lagoonal environment on 20 October 2020 at Blue Heron Bridge, Riviera Beach $\left(26.7844^{\circ} \mathrm{N}, 80.0484^{\circ} \mathrm{W}\right)$, based on unverified sightings of individuals of $O$. mirabilis at this locality. After about one hour of searching, 10 individuals of $O$ mirabilis were observed on one of several colonies of the plumulariid hydrozoan [Dentitheca dendritica (Nutting, 1900)] examined (Fig. 2). Note salmon-pink patches and all individuals in different stages of fissiparity. The hydroid host colony, robust and arborescent in growth form (Calder, 2013), was attached to the substrate under the bridge in the intracoastal waterway. Circulation at this location was strong, with a twice-daily tidal influx of ocean water.

Initial field evidence suggesting that interspecific interactions between brittle stars and ctenophores might be responsible for abundance differences (including absences) was evident from sequential sampling at the Dania Beach study site. Across 16 quantitative surveys over a 19 month period, mean densities of individuals of $C$. waltoni ranged from 0 to 30.9 individuals per $10 \mathrm{~cm}$ octocoral branch length, mean densities of individuals of 0 . mirabilis ranged from 0 to 30.5, and mean densities of individuals of $C$. penantis ranged from 0 to 10 (Fig. 3). Based on the first statistical model (correlation based $\mathrm{R}^{2}=0.48$ ), there was strong evidence that trends in epizoite densities inhabiting octocoral hosts differed by species across the survey period $(\mathrm{p}<0.0001)$. This was driven specifically by a decline in $C$. waltoni over time $(\mathrm{p}=$ 0.0006), which exhibited an average reduction in population size of $9.2 \%$ every 30 days ( $95 \% \mathrm{Cl}: 4.1 \%$ to $14.0 \%)$. Overall trends in either direction were not significant for 0 . mirabilis $(p=0.31)$ or $C$. penantis $(p=$ $0.073)$.

\section{Laboratory experiment}

After accounting for the overall trend in total numbers of $C$. waltoni, the second statistical model (correlation-based $\mathrm{R}^{2}=0.51$ ) revealed that an association between the abundance of $C$. waltoni and counts of $O$. mirabilis was still quite evident $(p=0.0007)$. For each additional $O$. mirabilis individual present per $10 \mathrm{~cm}$ branch length, the abundance of $C$. waltoni displayed an expected $3.8 \%$ decline $(95 \%$ Cl: $1.6 \%$ to $6.0 \%)$. In contrast, the abundance of $C$. waltoni showed evidence of a second order 
relationship with counts of $C$. penantis $(p=0.016)$, exhibiting a positive association within the limited range of individuals observed. There was no evidence to suggest that these relationships varied over time.

Based on analysis of the laboratory experiment there was strong evidence that the presence of $O$. mirabilis negatively impacted the density of $C$. waltoni $(=18.9, p=0.0003$, Fig. 4). Mean (se) $C$. waltoni density in the control group began at $7.6(0.75)$ and declined to $5.0(0.55)$ individuals $/ 10 \mathrm{~cm}$ branch length by day seven, while in the brittle star group mean density declined from $7.2(0.49)$ to $1.0(0.63)$ individuals $/ 10 \mathrm{~cm}$ branch length. Ctenophores on octocoral branches remained roughly evenly spaced in the control group, but clearly clumped at the ends of branches, separated from the ophiuroids, in the experimental treatment.

Behavioral observations

Interspecific behaviors were documented to gain insight into interactions possibly affecting epizoite abundances. Field observations of $O$. mirabilis revealed frequent suspension feeding during day and night with arms greatly extended and waving (as if searching) in passing currents. Occasionally unidentified items were captured, conveyed to the mouth and presumably ingested. Identical activities were observed in the laboratory during feeding trials when offered Artemia nauplii.

Individuals of $C$. waltoni were nearly always inactive, firmly attached to coenosarc surfaces, and often near polyp bases with tentacles fully contracted (Table 1 ). When individuals of $C$. waltoni were contacted by $O$. mirabilis, this often caused the ctenophore to move. In one instance, contact by $O$. mirabilis caused rapid contraction with the ctenophore assuming a crinkled body shape (see Fig. 3 I in Glynn et al. 2014).

In two collections with individuals of the caprellid (Caprella penantis) present, $16.2 \%$ (5 of 31) and 100\% (1 of 1 ) of the individuals of $C$. waltoni in the samples were attacked and eaten; no ctenophores were attacked in two collections (Table 1). The caprellid was not necessarily common, but when present effected intense predation on the ctenophore. The predatory caprellids in the 17 March sample moved quickly along the octocoral branch, ostensibly in a search mode; as soon as a ctenophore was encountered it was grasped, shredded, and consumed. In this same sample, two caprellids separately attacked an individual of $O$. mirabilis, but failed to penetrate the epidermis; each caprellid then moved further along the branch after a few seconds.

When present at moderate and high densities the ophiuroids were generally evenly spaced along the octocoral branch. However, in two high density collections (September, November, Table 1) the ophiuroids were densely crowded with arms and discs overlapping. Ctenophores were not present in or near these aggregations.

\section{Discussion}


Our systematic surveys over a one-year period have demonstrated the presence of individuals of $O$. mirabilis at moderate to high abundances from Hollywood Beach to West Palm Beach, a distance along the coast of about $78 \mathrm{~km}$. The clusters of high survey abundances immediately north and about $4 \mathrm{~km}$ south of the entrance to Port Everglades lend support to the hypothesized localized introduction of this exotic ophiuroid via high volume ship traffic (Glynn et al. 2020) as also proposed in several studies in Brazil (Hendler and Brugneaux, 2013; Bumbeer and Rocha, 2016; Mantelatto et al., 2016; Araújo et al., 2018; Lawley et al., 2018).

In just 20 years, individuals of 0 . mirabilis have colonized coastlines spanning more than $6,000 \mathrm{~km}$ of latitude (Tavares et al. 2021), from their first reported presence in southern Brazil (Hendler et al. 2012) northward along the South American coast to the Caribbean Sea (Hendler and Brugneaux 2013; Ferry et al. 2020) and southeastern Florida (Glynn et al. 2019). Their northern-most occurrence on the Florida east coast, observed on 28 September 2019, was at Deerfield Beach, $26.3184^{\circ} \mathrm{N} ; 80.0998^{\circ} \mathrm{W}$ (Glynn et al. 2020). In the present study, individuals of O.mirabilis were found on a hydrozoan colony at Blue Heron Bridge, Riviera Beach, $26.7153^{\circ} \mathrm{N} ; 80.0534^{\circ} \mathrm{W}$ on 20 October $2020,44 \mathrm{~km}$ north of Deerfield Beach in a brackish environment. It is not known if this record represents migration over a one-year period or if the ophiuroids were already present there and un-reported. The near absence of shallow water octocorals in the vicinity of St. Lucie Inlet (Martin County), nearly 50 km north of Deerfield Beach (Jones et al. 2020) would not seem likely to inhibit a more northern range extension of individuals of $O$. mirabilis since this ophiuroid is known to associate with numerous other taxa in Florida (Glynn et al., 2020), Brazil (Bumbeer and Rocha, 2016; Mantelatto et al., 2016; Fortunato and Lôbo-Hajdu, 2021), and the eastern Pacific (Granja-Fernández et al., 2014). However, the present distributions of non-native western Atlantic and native eastern Pacific $O$. mirabilis are generally restricted to these amphiamerican tropical/subtropical biogeographic realms (Costello et al. 2017; Travares et al. 2020).

An ecological niche model analysis, employed by Derviche et al. (2021), based on current $O$. mirabilis distributions and abundances, predicted suitable western Atlantic habitats beyond present-day occurrences and widespread dispersion and range expansion in the future. They reported that the occurrence of $O$. mirabilis correlates chiefly with mean calcite concentration and mean sea surface temperature. If this prediction is realized the ophiuroid could colonize numerous suitable habitats in warm temperate southwestern and northwestern Atlantic environments. This would include range expansions to southeastern Brazil and to the Carolinian province along the east coast of the USA. Also included would be large areas of the Caribbean Sea and the northern Gulf of Mexico. Derviche and coworkers suggested that the calcite mineral would be required for ophiuroid skeletogenesis, especially during asexual fissiparity, and that physiological functions are impaired at mean sea temperatures less than $21.75^{\circ} \mathrm{C}$. These workers also noted increasing population densities of 0 . mirabilis from inner shelf to estuarine habitats at the Paranaguá estuarine complex in southern Brazil.

Marked variability occurred in epizoite densities in the 16 collections over the 19-month sampling period as reported in prior studies in southeast Florida (Glynn et al. 2020). For individuals of 0 . mirabilis and $C$. waltoni this is probably in part a reflection of the patchy occurrence and the sampling protocol for these 
species; the identical octocoral patches, colonies, and branches were not repeatedly sampled at the Dania Beach study site. The occurrence of individuals of Caprella penantis was sporadic, observed in only four collections. Aquarium observations revealed this amphipod to be highly mobile, moving quickly over a given octocoral branch, and often swimming and moving between branches. It is likely that this predatory amphipod naturally moves frequently among octocoral branches within and among colonies in search of prey.

Ophiuroids were not present on dead octocoral branches (Glynn et al. 2020). Their absence could offer a refuge for $C$. waltoni, however, the ctenophore was absent from dead branches as well. Dead branches are usually quickly colonized by algae and hydroids, a likely inhospitable habitat for mobile epizoites. Live octocoral host tissues bearing nematocysts, sclerites, and chemical defenses (Pawlik et al., 1987; Harvell and Fenical 1989; Yoffe et al., 2012) would provide an advantage in predator avoidance, thus offering a suitable microhabitat.

Since octocorals engage heavily in suspension feeding, capturing particulate organic matter (Lasker, 1981) and microzooplankton (Glynn et al. 2018a), the interference of polyp expansion by individuals of $O$. mirabilis was suggested to be a potentially significant threat against satisfying the trophic requirements of octocoral hosts (Araújo et al. 2018; Ferry et al. 2020), although a recent study suggests this may not be consequential (Glynn et al., 2021). From the current study - which has demonstrated an inverse relationship in the abundance of ophiuroids and ctenophores in field collections, and decreasing ctenophore abundance in the presence of ophiuroids in a laboratory experiment - it appears that the major effect of the exotic ophiuroid is on the displacement, by interference competition, of the cohabiting benthic ctenophore. This sort of negative impact on biodiversity is the predominant effect of marine invasive species in European seas (Katsanevakis et al. 2014). It is not yet known if 0 . mirabilis will negatively impact the abundances of octocoral hosts, but if this occurs then local biodiversity would be greatly diminished. Invasive azooxanthellate sun corals are displacing ecosystem engineers (e.g., reefbuilding corals and zoantharians) in Brazil, having a depressing effect on biodiversity, nearly two decades after their first sightings (Miranda et al., 2016; Luz and Kitahara, 2017). It is too early to determine the extent to which the ophiuroid will continue to affect $C$. waltoni, and perhaps begin to impact octocorals and other epizoites.

Several studies have described the kleptocommensal and kleptoparasitic trophic relationships of hydroids and other invertebrate epizoites associated with sponges, octocorals, bryozoans, and polychaete worms (e.g., Gotto, 1969; Puce et al., 2008). Bavestrello et al. (1996) observed caprellids seizing previously captured nauplii from hydroid polyps; a nudibranch grazing preferentially on hydroid polyps that previously ingested zooplankton, an example of the consumption of a prey item plus its ingested prey, was termed kleptopredation by Willis et al. (2017). The symbiotic status of the benthic ctenophore and its octocoral host is not clear since we have observed the ctenophore purloining food (unidentified organic detritus) captured by its host's polyps, and octocoral polyps have been observed removing captured fish eggs from the tentacles of ctenophore epizoites (Glynn et al. 2018a). Further study is 
necessary to determine the significance of these trophic resources, the relative amounts garnered by the symbiotic partners, and how field conditions affect these interactions.

The alacrity with which individuals of Caprella penantis attacked, shredded and consumed relatively large fragments of benthic ctenophores suggests that this crustacean species is an occasional, if not frequent, predator of individuals of $C$. waltoni. No defensive responses by $C$.waltoni, such as rapid tentacle extension (Glynn et al., 2018b), were observed beyond slow fleeing movements, which were ineffective. From feeding observations conducted in northern Florida, Gulf of Mexico, Caine (1974) noted that individuals of $C$. penantis depended primarily on filter feeding and substrate scraping. Contrary to the observations of Caine (1974) and Paz-Rios et al. (2014) on the relative ineffectiveness of caprellids as predators, we observed that all individuals engaged in feeding moved quickly over octocorals, occasionally swimming, potentially in search of ctenophore prey. This is the first documented record of a ctenophore species consumed by a caprellid (Saunders, 1966; Sano et al., 2003; Guerra-García and Tierno de Figueroa, 2009). Most caprellids are detritivores, $86 \%$ in the global survey conducted by Guerra-García and Tierno de Figueroa (2009); however, several species are facultative and obligate predators, consuming sponges, polychaete worms, copepods and amphipods.

If the recent decline in abundance of $C$. waltoni, and local disappearance at some sites, is due primarily to 0 . mirabilis, then it is necessary to understand how this occurs. The ctenophores are exceedingly well camouflaged and typically quiescent when present on their octocoral hosts. Once a ctenophore has found a favorable perch for the extension of its 'fishing' tentacles, movement is infrequent. Our observations indicate that brittle star contact with individuals of $C$. waltoni is an irritation, often causing the ctenophores to move. We hypothesize that ctenophores on the move are more susceptible to dislodgment from their octocoral hosts. Dislodgment could occur during turbulent sea conditions, which are frequent off the southeast coast of Florida, or by fishes and other water column predators.

A notable report of a caprellid infestation and predation on gorgonian sea fans in North Sulawesi, Indonesia, revealed massive consumption of coenenchyme (octocoral tissues including epidermis, mesoglea and gastrodermis) and skeletal fragments resulting in total colony mortality in three species (Scinto et al., 2008). Octocoral colonies of Melithaea sp. were most severely affected, irreparably damaged within a week. The caprellid responsible for the sea fan mortality was Metaprotella sandalensis, a common species on Indo-Pacific coral reefs. The morphology of the feeding appendages (molar process and mandibular palp) are characteristic of caprellid predators and scrapers (Caine, 1977; Guerra-García and Tierno de Figueroa, 2009). Mean caprellid infestation densities were $8.5 \mathrm{ind} \mathrm{cm}^{-1}$ branch, equivalent to 85 individuals over a $10 \mathrm{~cm}$-long branch (Scinto et al., 2008; C. Cerrano, pers. comm.). These densities are an order of magnitude higher than those observed in south Florida (Table 1). Such a severe predation event triggering the death of entire gorgonian colonies, would also result in the loss of the associated symbiont community.

\section{Concluding remarks}


The ophiuroid invasion of octocorals in southeast Florida is very recent, making it difficult to predict longterm effects. The apparent ongoing displacement of an endemic benthic ctenophore is the only negative effect thus far observed. No obvious signs of impairment to octocoral hosts are evident (Glynn et al., 2021). In light of the ophiuroids establishment in southeastern Brazil, over a period of about 20 years, its rapid and wide-ranging dispersal and possible repeated introductions, it is highly probable that it will continue to spread and become established throughout the western Atlantic warm water region where octocorals and other suitable substrata occur. Since the invasion of $O$. mirabilis in the western Atlantic region is so recent and still on-going, we urgently encourage continuing surveys to document its occurrence, abundance, and interactions with native species. Coastal and estuarine habitats with suitable environmental conditions in need of surveys and study are the Tropical Northwestern Atlantic province (wider Caribbean Sea) and the Warm Temperate Southwestern (southeastern Brazil) and Northwestern Atlantic (Northern Gulf of Mexico, Carolinian) provinces. Behavioral and experimental studies of alien brittle star interactions vis-a-vis native epizoites are especially encouraged and may shed light on control measures should these be needed. Cryptogenic C.penantis should also receive attention considering its predatory impacts on $C$. waltoni and other octocoral epizoites.

\section{Declarations}

Acknowledgments Thanks are due W. L. Bullock (Landis), B. Enright, R. L. Ionata, and the South Florida Beach Divers Meetup Group for help with obtaining collections, and to Markus Niemeyer for the report and specific location data on O. mirabilis at Blue Heron Bridge. A special thanks to Julie Gross for sundry laboratory tasks and enlightening discussions. R. C. Brusca, D. Cadien, D. Drumm, and Lea-Anne Henry offered literature sources, helpful discussions, and contacts with systematists for species identifications. J. M. Guerra-García kindly identified Caprella penantis. and Dale R. Calder a hydrozoan. We are grateful for details on the Bunaken caprellid infestations provided by Carlo Cerrano. The Ophiothela collection at Blue Heron Bridge was under FWC Special Activity License SAL-20-2267-SR.

\section{Compliance with Ethical Standards:}

Funding: No funding was received for this study.

Conflict of Interest: All authors declare that they have no conflicts of interest. ...

Ethical approval: All applicable international, national, and/or institutional guidelines for the care and use of animals were followed. Experiments and observations involving the invertebrates were approved by the IACUC committees at UM and NSU. The Ophiothela collection at Blue Heron Bridge was under FWC Special Activity License SAL-20-2267-SR.

\section{References}

1. Alitto RAS, Granadier G, Christensen AB, O'Hara T, Domenico M D, Borges M (2020) Unravelling the taxonomic identity of Ophiothela Verrill, 1867 (Ophiuroidea) along the Brazilian coast. Journal of the 
Marine Biological Association of the United Kingdom 1-14 https://doi.org/10.1017/S002531542000034X

2. Anton A, Geraldi NR, Lovelock CE et al. (2019). Global ecological impacts of marine exotic species. Nat Ecol Evol 3:787-800 (2019) https://doi.org/10.1038/s41559-019-0851-0

3. Araújo J T de, Soares M O, Matthews-Cascon H, Monteiro FAC (2018) The invasive brittle star Ophiothela mirabilis Verrill, 1867 (Echinodermata, Ophiuroidea) in the southwestern Atlantic: filling gaps of distribution, with comments on an octocoral host. Latin American Journal of Aquatic Research 46(5):1123-1127 DOI: 10.3856/vol46-issue5-fulltext-25

4. Bartier $P$ M, Keller C P (1996) Multivariate interpolation to incorporate thematic surface data using inverse distance weighting (IDW). Computers \& Geosciences 22(7):795-799 https://doi.org/10.1016/0098-3004(96)00021-0

5. Bavestrello G, Cerrano C, Cattaneo-Vietti R, Sarà M (1996) Relations between Eudendrium glomeratum (Cnidaria, Hydromedusae) and its associated vagile fauna. Scientia Marina 60 (1):137143

6. Bayer FM (1961) The shallow-water Octocorallia of the West Indian region, A manual for marine biologists pp 1-373 The Hague, Martinus Nijhoff.

7. Brooks ME, Kristensen K, van Benthem KJ, Magnusson A, Berg CW, Nielsen A, Skaug HJ, Maechler M, Bolker BM (2017) glmmTMB balances speed and flexibility among packages for zero-inflated generalized linear mixed modeling. The R Journal, 9(2), 378-400 https://journal.rproject.org/archive/2017/RJ-2017-066/index.html

8. Buhl-Mortensen L, Vanreusel A, Gooday A J, Levin L A, Priede I G, Buhl-Mortensen P, Gheerardyn H, King N J, Raes $M$ (2010) Biological structures as a source of habitat heterogeneity and biodiversity on the deep ocean margins. Marine Ecology 31:21-50 doi:10.1111/j.1439-0485.2010.00359.x

9. Bumbeer J, Rocha R M (2016) Invading the natural marine substrates: a case study with invertebrates in South Brazil. Zoologia (Curitiba) 33 (3) e20150211 https://doi.org/10.1590/S19844689zool-20150211

10. Cabezas MP, Cabezas P, Marchordom A, Guerra-García JM (2013) Hidden diversity and cryptic speciation refute cosmopolitan distribution in Caprella penantis (Crustacea: Amphipoda: Caprellidae). Zool. Syst. Evol. Res. 51(2):85-99

11. Caine EA (1974) Comparative functional morphology of feeding in three species of caprellids (Crustacea, Amphipoda) from the northwestern Florida Gulf Coast. J. Exp. Mar. Biol. Ecol. 15:81-96

12. Caine EA (1977) Feeding mechanisms and possible resource partitioning of the Caprellidae (Crustacea: Amphipoda) from Puget Sound, USA. Mar. Biol. 42:331-336

13. Calder DR (2013) Some shallow-water hydroids (Cnidaria: Hydrozoa) from the central east coast of Florida, USA. Zootaxa 3648 (1):001-072 http://dx.doi.org/10.11646/zootaxa.3648.1.1

14. Costello MJ, Tsai P, Wong PS et al. (2017) Marine biogeographic realms and species endemicity. Nat Commun8, 1057 (2017). https://doi.org/10.1038/s41467-017-01121-2 
15. Derviche P, Saucsen A, Spier D, Lana P (2021) Distribution patterns and habitat suitability of the nonnative brittle star Ophiothela mirabilis Verrill, 1867 along the western Atlantic. J Sea Res 168 (2021) 101994

16. De Paula AF, Creed JC (2004) Two species of the coral Tubastraea (Cnidaria, Scleractinia) in Brazil: a case of accidental introduction. Bull Mar Sci 74:175-183

17. Fenner D (2001) Biogeography of three Caribbean corals (Scleractinia) and the invasion of Tubastraea coccinea into the Gulf of Mexico. Bull Mar Sci 69:1175-1189

18. Fenner D, Banks K (2004) Orange cup coral Tubastraea coccinea invades Florida and the Flower Garden Banks, northwestern Gulf of Mexico. Coral Reefs 23:505-507

19. Ferry R, Hubert L, Philippot V, Priam F, Smith J (2020) First record of the non-indigenous brittle star species Ophiothela mirabilis Verrill, 1867 (Echinodermata: Ophiuroidea), off Martinique Island, French Lesser Antilles. Biolnvasions Records 9(2):228-238

20. Fortunato HFM, Lôbo-Hajdu G (2021) Quantification of the non-indigenous ophiuroid Ophiothela mirabilis Verrill, 1867 associated with marine sponges with different morphologies. Aquatic Invasions 16(1):77-93 https://doi.org/10.3391/ai.2021.16.1.06

21. Glynn PW, Bayer FM, Renegar DA (2014) Coeloplana waltoni, a new species of minute benthic ctenophore (Ctenophora: Platyctenida) from south Florida. Proc Biol Soc Wash 127:423-436.

22. Glynn PW, Coffman B, Fuller MPC, Moorhead SG, Williams MK, Primov KD, Fortson TN, Barrales RN, Glynn PJ (2017) Benthic ctenophores (Platyctenida: Coeloplanidae) in south Florida: environmental conditions, habitats, abundances, and behaviors. Invert. Biol. 136(4):379-393. DOI:

10.1111/ivb.12189

23. Glynn PW, Coffman B, Primov KD, Moorhead SG, Vanderwoude J, Barrales RN, Williams MK, Roemer RP (2018a) Benthic ctenophores (Platyctenida: Coeloplanidae) in South Florida: predator-prey interactions. Invert Biol 137(2):133-150

24. Glynn PW, Coffman B, Vanderwoude J, Martinez N, Dominguez JH, Gross JM, Renegar DA (2018b) Antipredatory escape behaviors of two benthic ctenophores in South Florida. Ecology 100 (1) https://doi.org/10.1002/ecy.2497

25. Glynn PW, Alitto R, Dominguez J, Christensen AB, Gillette P, Martinez N, Riegl BM, Dettloff K (2020) A tropical eastern Pacific invasive brittle star species (Echinodermata: Ophiuroidea) reaches southeastern Florida. Adv. Mar. Biol. 87:443-472

26. Glynn PW, Gillette PR, Dettloff K, Dominguez J, Martinez N, Gross J, Riegl BM (2021). Experimental evidence of minimal effects on octocoral hosts caused by the introduced ophiuroid Ophiothela mirabilis Coral Reefs https://doi.org/10.1007/s00338-021-02067-0

27. Goh NKC, Ng PKL, Chou LM (1999) Notes on the shallow water gorgonian-associated fauna on coral reefs in Singapore. Bull. Mar. Sci. 65 (1):259-282

28. Gotto RV (1969) Marine animals: partnerships and other associations. American Elsevier Pub. Co., Inc., New York 
29. Granja-Fernández R, Herrero-Pérezrul MD, López-Pérez RA, Hernández L, Rodríguez-Zaragoza FA, Jones RW, Pineda-López R (2014) Ophiuroidea (Echinodermata) from coral reefs in the Mexican Pacific. Zookeys 406:101-145

30. Guerra-García JM, Tierno de Figueroa JM (2009) What do caprellids (Crustacea: Amphipoda) feed on? Mar Biol 156:1881-1890

31. Harvell CD, Fenical W (1989) Chemical and structural defenses of Caribbean gorgonians (Pseudopterogorgia): intracolony localization of defense. Limnol Oceanogr 34(2):382-389

32. Hendler G, Brugneaux SJ (2013) New records of brittle stars from French Guiana: Ophiactis savignyi and the alien species Ophiothela mirabilis (Echinodermata: Ophiuroidea). Mar Biodivers Rec 6, e113 https://doi.org/10.1017/s1755267213000845

33. Hendler G, Migotto AE, Ventura CRR, Wilk L (2012) Epizoic Ophiothela brittle stars have invaded the Atlantic. Coral Reefs, 31,1005 DOI: 10.1007/s00338-012-0936-6

34. Jones NP, Figueiredo J, Gilliam DS (2020) Thermal stress-related spatiotemporal variations in highlatitude coral reef benthic communities. Coral Reefs https://doi.org/10.1007/s00338-020-01994-8

35. Katsanevais S, Wallentinus I, Zenetos A, Leppäkosi E, Çinar ME, Oztürk B, Grabowksi M, Golani D, Cardoso AC (2014) Impacts of invasive alien marine species on ecosystem services and biodiversity: a pan-European review. Aquat Invasions 9(4):391-423

36. Lages BG, Fleury BG, Menegola C, Creed JC (2011) Change in tropical rocky shore communities due to an alien coral invasion. Mar Ecol Prog Ser 438:85-96 DOI: 10.3354/meps09290

37. Lasker HR (1981) A comparison of the particulate feeding abilities of three species of gorgonian soft coral. Mar Ecol Prog Ser 5:61-67

38. Lawley JW, Fonseca AC, Faria Júnior E, Lindner A (2018) Occurrence of the non-indigenous brittle star Ophiothela mirabilis Verrill, 1867 (Echinodermata: Ophiuroida) in natural and anthropogenic habitats off Santa Catarina, Brazil. Check List 14, 453-459 https://doi.org/10.15560/14.2.453

39. Luz BLP, Kitahara MV (2017) Could the invasive scleractinians Tubastraea coccinea and tagusensis replace the dominant zoantharian Palythoa caribaeorum in the Brazilian subtidal? Coral Reefs 36:875 DOI 10.1007/s00338-017-1578-5

40. Maggioni D, Montano S, Voigt O, Seveso D, Galli P (2020) A mesophotic hotel: the octocoral Bebryce grandicalyx as a host. Ecology 101(4) e02950 https://doi.org/10.1002/ecy.2950

41. Mantelatto MC, Vidon LF, Silveira RB, Menegola C, Moreira da Rocha R, Creed JC (2016) Host species of the non-indigenous brittle star Ophiothela mirabilis (Echinodermata: Ophiuroidea): an invasive generalist in Brazil? Marine Biodiversity Records, 9:8. DOI 10.1186/s41200-016-0013-x

42. McCauley M, Jackson CR, Goulet TL (2020) Microbiomes of Caribbean octocorals vary over time but are resistant to environmental change. Front. Microbiol. https://doi.org/10.3389/fmicb.2020.01272

43. Miranda RJ, Cruz ICS, Barros F (2016) Effects of the alien coral Tubastraea tagusensis on native coral assemblages in a southwestern Atlantic coral reef. Mar Biol 163:45 DOI 10.1007/s00227-0162819-9 
44. Pawlik JR, Burch MT, Fenical W (1987) Patterns of chemical defense among Caribbean gorgonian corals: a preliminary survey. J Exp Mar Biol Ecol 108:55-66

45. Paz-Ríos CE, Guerra-García JM, Ardisson P-L (2014) Caprellids (Crustacea: Amphipoda) from the Gulf of Mexico, with observations on Deutella mayeri, redescription of Metaprotella hummelincki, a taxonomic key and zoogeographical comments. J Nat Hist 48(41-42):2517-2578

46. Pinheiro JC, Bates DM (2000) Mixed-effects models in S and S-PLUS. New York, Springer

47. Puce S, Di Camillo CG, Bavestrello G (2008) Hydroids symbiotic with octocorals from the Sulawesi Sea, Indonesia. J Mar Biol Ass U K 88 (08):1643-1654

48. Pyšek P, Hulme PE, Simberloff D, Bacher S, Blackburn TM, Carlton JT, Dawson W, Essl F, Foxcroft LC, Genovesi $P+13$ others (2020) Scientists' warning on invasive alien species. Biol Rev doi:10.1111/brv.12627

49. Sammarco PW, Porter SA, Genazzio M, Sinclair J (2015) Success in competition for space in two invasive coral species in the western Atlantic - Tubastraea micranthus and coccinea. PLoS ONE 10(12):e0144581 https://doi.org/10.1371/journal.pone.0144581

50. Sánchez JA (2016) Diversity and evolution of octocoral animal forests at both sides of tropical America. In: S Rossi, ed, pp 2-33, Marine Animal Forests, Springer Int. Pub. DOI 10.1007/978-3-31917001-5_39-1

51. Sánchez JA, Wirshing HH (2005) A field key to the identification of tropical Western Atlantic zooxanthellate octocorals (Octocorallia: Cnidaria). Carib J Sci 41:508-522

52. Sano M, Omori M, Taniguchi K (2003) Predator-prey systems of drifting seaweed communities off the Tohoku coast, northern Japan, as determined by feeding habitat analysis of phytal animals. Fish Sci 69:260-268 Doi: 10.1046/j.1444-2906.2003.00616.x

53. Saunders CG (1966) Dietary analysis of caprellids (Amphipoda). Crustaceana 10:314-316

54. Sax DF, Gaines SD (2008) Species invasions and extinctions: the future of native biodiversity on islands. Proc Nat Acad Sci 105:11490-11497 doi/10.1073/pnas.0802290105

55. Scinto A, Bavastrello G, Boyer M, Previati M, Cerrano C (2008) Gorgonian mortality related to a massive attack by caprellids in the Bunaken Marine Park (North Sulawesi, Indonesia). J Mar Biol Assoc UK http:hdl.handle.net/11567/226614

56. Seebens H, Blackburn T, Dyer E et al. (2017) No saturation in the accumulation of alien species worldwide. Nat Commun 8, 14435 https://doi.org/10.1038/ncomms14435

57. Tavares MR, Franco ACS, Ventura CRR, Santos LN (2021) Geographic distribution of Ophiothela brittle stars (Echinodermata: Ophiuroidea): substrate use plasticity and implications for the silent invasion of mirabilis in the Atlantic. Hydrobiologia https://doi.org/10.1007/s10750-020-04505-6

58. Van Oppen MJH, Mieog JC, Sánchez CA, Fabricius KE (2005) Diversity of algal endosymbionts (zooxanthellae) in octocorals: the roles of geography and host relationships. Mol Ecol 14(8): 240317.doi: 10.1111/j. 1365-294X.2005.0254.x 
59. Verrill AE (1867) Note on the Radiata in the Museum of Yale College, with descriptions of new genera and species. Notes on the echinoderms of Panama and the west coast of America with descriptions of new genera and species. Trans Connecticut Acad Arts Sci 1 (2):251-322

60. Willis TJ, Berglöf KTL, McGill RAR, Musco L, Piraino S, Rumsey CM, Fernández TV, Badalamenti F (2017) Kleptopredation: a mechanism to facilitate planktivory in a benthic mollusc. Biology Letters 13:20170447. http://dx.doi.org/10.1098/rsbl.2017.0447

61. Yoffe C, Lotan T, Benayhau Y (2012) A modified view on octocorals: Heteroxenia fuscescens nematocysts are diverse, featuring both an ancestral and a novel type. PLoS One 7(2):e31902. doi: 10.1371/journal.pone.0031902

\section{Tables}

Table 1. Co-occurrence and behavior of epizoites on plexaurid octocoral hosts observed in the laboratory. From Dania Beach collections.

\begin{tabular}{|c|c|c|c|c|}
\hline Collection & $n^{1}$ & Mean density ${ }^{2}$ & $\begin{array}{l}\text { Predation } \\
(C W \\
\rightarrow C p)^{3}\end{array}$ & Observations \\
\hline & & C.w./O.m./C.p. & $\begin{array}{l}\text { No. } \\
\%\end{array}$ & \\
\hline $\begin{array}{l}5 \text { January } \\
2019\end{array}$ & 16 & $4.5 / 27.0 / 0$ & $\begin{array}{l}0 \\
0\end{array}$ & O.m. arm briefly contacting C.W., no response \\
\hline $\begin{array}{l}17 \text { March } \\
2019\end{array}$ & 20 & $30.9 / 14.0 / 10.0$ & $\begin{array}{l}5 \\
16.2\end{array}$ & $\begin{array}{l}\text { C.p. moving rapidly along branches locating and } \\
\text { quickly shredding } C . W \text {. tissues with ingestion. } \\
\text { Two C.p. unsuccessfully attacked } O . m \text {., but could } \\
\text { not cut through epidermal armor. O.m. arm } \\
\text { contacted } C . W \text {. aboral surface, C.W. contracted } \\
\text { into spherical shape. C.W. on octocoral stem } \\
\text { away from } O . m \text {. }\end{array}$ \\
\hline $\begin{array}{l}21 \text { April } \\
2019\end{array}$ & 39 & 7.6/7.3/0.2 & $\begin{array}{l}0 \\
0\end{array}$ & $\begin{array}{l}\text { C.W. moved when brushed by arms of } O . m \text {. C.p. } \\
\text { with amorphous detritus in gnathopod,but not } \\
\text { ingested. }\end{array}$ \\
\hline $\begin{array}{l}27 \\
\text { October } \\
2019\end{array}$ & 25 & $2.1 / 6.0 / 3.3$ & $\begin{array}{l}0 \\
0\end{array}$ & $\begin{array}{l}\text { C.W. inactive. O.m. active with arm waving. C.W. } \\
\text { moved when contacted by O.m. C.p. actively } \\
\text { moving along branches. }\end{array}$ \\
\hline $\begin{array}{l}8 \\
\text { November } \\
2019\end{array}$ & 26 & $0.4 / 18.2 / 0$ & $\begin{array}{l}0 \\
0\end{array}$ & O.m. aggregating at high density \\
\hline $\begin{array}{l}5 \\
\text { December } \\
2019\end{array}$ & 30 & 1.0/19.5/0.3 & $\begin{array}{l}1 \\
100.0\end{array}$ & $\begin{array}{l}\text { O.m. and C.p. in intermittent contact, no } \\
\text { interaction. One C.p. quickly shredded and } \\
\text { ingested one C.W. }\end{array}$ \\
\hline
\end{tabular}


${ }^{1}$ Number of $10-\mathrm{cm}$ long octocoral branches observed. Observation time for all samples $\leq 2 \mathrm{hr}$.

${ }^{2}$ Mean values are for epizoite densities on 10-cm octocoral branches. C. $w_{.}=$Coeloplana waltoni; $0 . m .=$ Ophiothela mirabilis; C.p. = Caprella penantis. Observed microscopically (10-30X) under subdued lighting.

${ }^{3}$ Total number of C.W. (prey) attacked and consumed by C.p. (predator). Percent values denote the proportion of all individuals of $C$. waltoni present on a single sampled branch that were consumed.

\section{Figures}

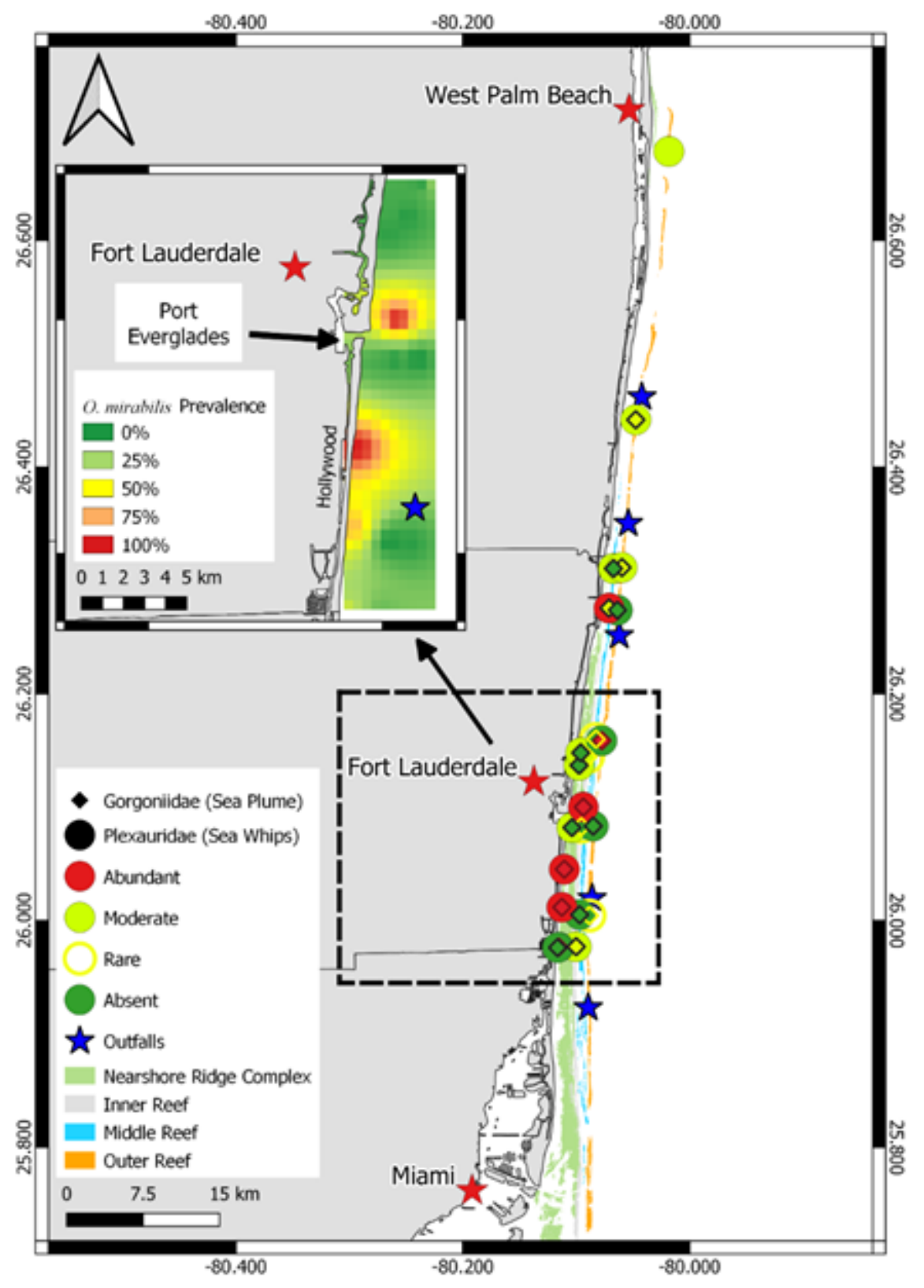

Figure 1 
O. mirabilis occurrence and abundance in southeast Florida. Main key: Qualitative abundance categories of 0 . mirabilis on plexaurid (sea whips, genera Eunicea and/or Muricea; represented by circles) and gorgoniid (sea plume, genus Antillogorgia; represented by diamonds) colonies. Abundant $=0$. mirabilis present on over $20 \%$ of colonies, Moderate $=0$. mirabilis present on $5-19 \%$ of colonies, Rare $=0$. mirabilis present on $<5 \%$ of colonies, Absent $=0$. mirabilis not found at site. Ocean outfall locations, major cities and ports mapped for reference. Inset: Inverse distance weighted interpolation (IDW) of O. mirabilis prevalence around Port Everglades. Note: The designations employed and the presentation of the material on this map do not imply the expression of any opinion whatsoever on the part of Research Square concerning the legal status of any country, territory, city or area or of its authorities, or concerning the delimitation of its frontiers or boundaries. This map has been provided by the authors.

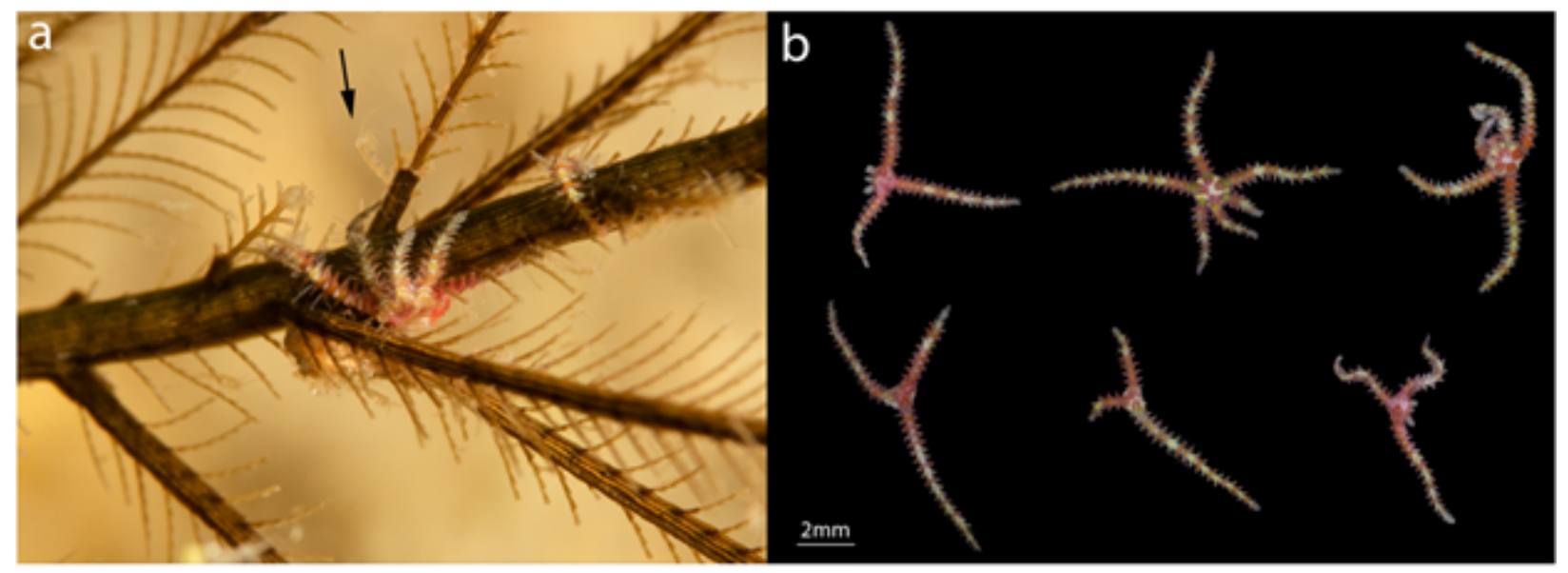

\section{Figure 2}

Ophiothela mirabilis. A, Adhering to hydrozoan colony Dentitheca dendritica under Blue Heron Bridge, Riviera Beach, Florida, 7 m depth, 28 July 2020; B, Six individuals from same hydrozoan in various stages of fissiparity. An arrow points to an unidentified caprellid amphipod. 


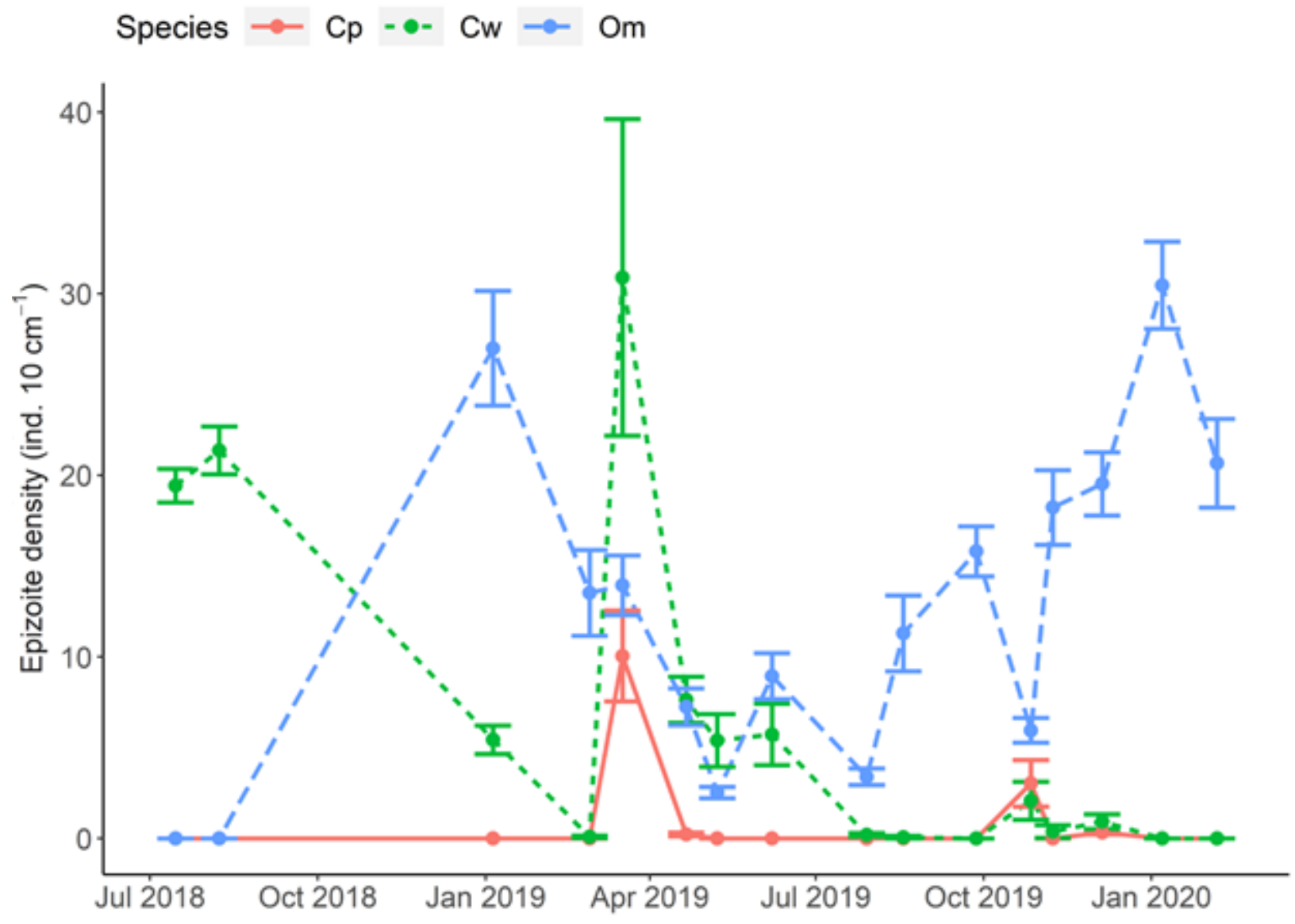

\section{Figure 3}

Mean (s.e.) sample densities of Ophiothela mirabilis, Coeloplana waltoni, and Caprella penantis in 16 collections over a 19-month period, July 2018-February 2020 at Dania Beach study site. Between 20 and $30,10-\mathrm{cm}$ long octocoral branches were examined in each collection. 


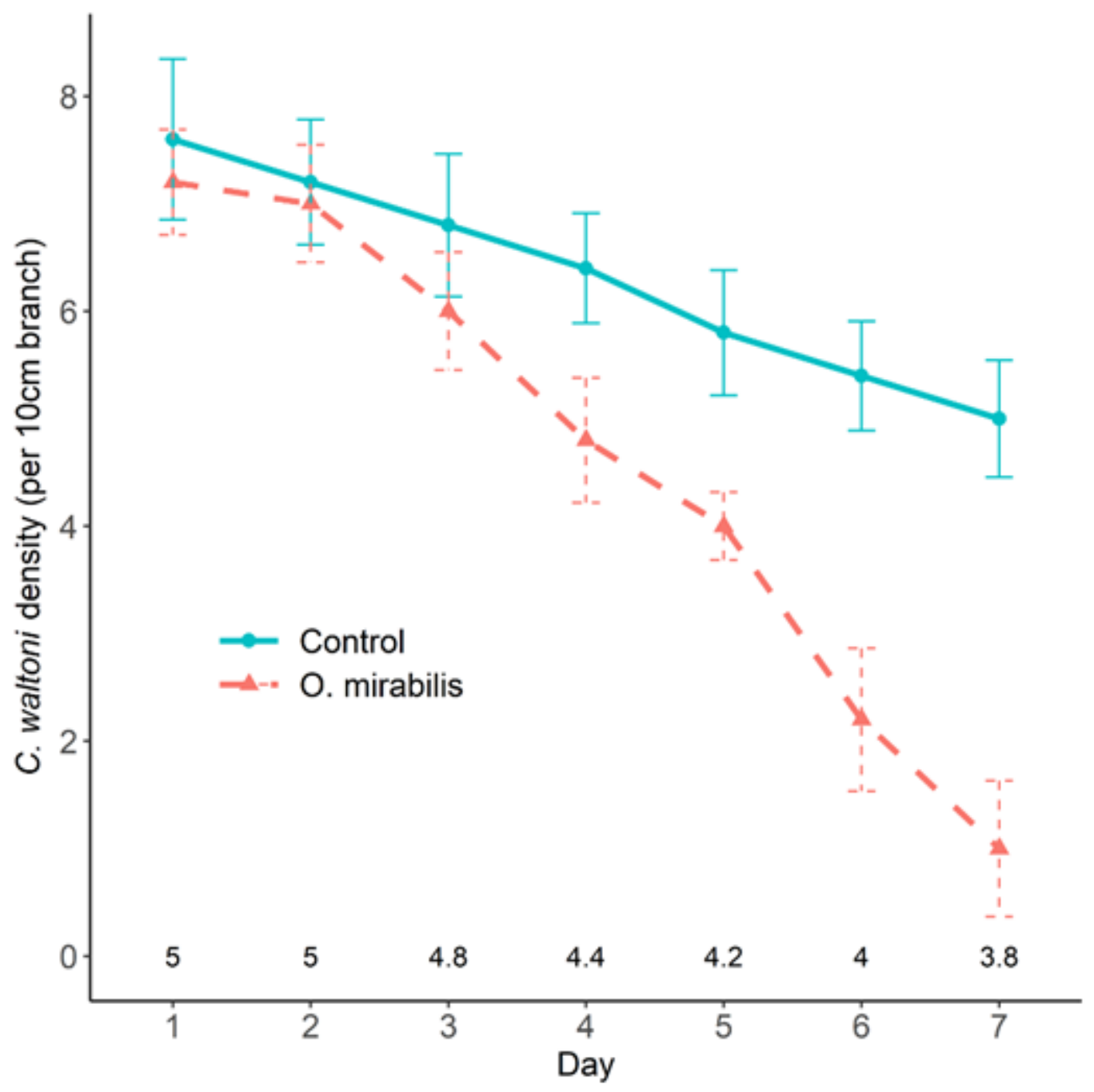

Figure 4

Coeloplana waltoni mean (s.e.) densities on octocoral branches over a 7-day experimental period in presence of brittle star Ophiothela mirabilis and absence (control). Mean daily O. mirabilis densities (no. inds. $\mathrm{cm}-1$ ) are noted along the abscissa. 